\title{
Side Plate Strength Analysis of the Mechanism for Vehicle Axle Scale Calibration
}

\section{Miroslav Blatnický1, Ján Dižo ${ }^{1}$, Mária Blatnická ${ }^{2}$}

${ }^{1}$ University of Žilina, Faculty of Mechanical Engineering, Department of Transport and Handling Machines, Univerzitná 8215/1, 01026 Žilina, Slovak Republic, e-mail: miroslav.blatnicky@fstroj.uniza.sk, jan.dizo@fstroj.uniza.sk

${ }^{2}$ University of Žilina, Faculty of Mechanical Engineering, Department of Applied Mechanics, Univerzitná 8215/1, 010

26 Žilina, Slovak Republic, e-mail: maria.blatnicka@fstroj.uniza.sk

This paper deals with the description of a mechanism for calibration vehicle axle scales with a loading capacity up to 10 tons and strength analysis of its selected part. The strength analysis will be carried out in ADINA software and this analysis results will be used to check the safety of the structure and in case of exceeding the permissible stress, deformation, etc. This analysis results will form a benchmark material for optimisation of this structure. The next step of this issue will be strength analyses of all important parts, i.e. boxes with weights and upper girder. After performing these calculations and the resulting optimisation, the prototype production will be feasible.

Keywords: Test device, Strenght analysis, ADINA software, Vehicle axle scale

\section{Acknowledgement}

This paper was created during the processing of the project "RAILBCOT-RAIL Vehicles Brake COmponents Test Stand", ITMS Code 26220220011 based on the support of Research and Development Operational Program financed by European Fund of a Regional Development. The work was also supported by the project No. APVV-0842-11: “Equivalent railway operation load simulator on the roller rig".

Research-Educational Center of Rail Vehicles (VVCKV)

\section{References}

[1] BALAJA, J., BRONČEK, J., ANTALA, J., SEKEREŠOVÁ, D. (2014). Mechanical Engineering Tables. (In Slovak). Selection Standard. Slovak Office Standards, Metrology and Testing, 2014. ISBN 978-80-8130-039-4.

[2] GALLIKOVÁ, J., POPROCKÝ, R. (2015). Maintenance according to the technical state with use of the enterprise asset management systems. In: Zeszyty naukowe Instytutu Pojazdów : mechanika, ekologia, bezpieczeństwo, mechatronika. - ISSN 1642-347X. - 3 (103)/(2015), Pp. 67-75.

[3] Gerlici, J., GORGUNOV, M., KRAVCHENKO, K., KOSTYUKEVICH, A., NOZHENKO, O., LACK, T. (2016). Experiemntal rigs for wheel/rail contact research. In: Manufacturing Technology. October 2016, Vol. 16, No. 5, 2016. Pp. 909-9016. ISSN 1213-2489.

[4] GERLICI, J., LACK, T. (2014). Rail vehicles brake components test utulisation. In: Applied Mechanics and Material. Vol. 486, 2014, Pp. 379-386. ISSN 1660-9336.

[5] GERLICI, J., LACK, T., HARUŠINEC, J. (2013). The test stand load modulus implementation for the realistic railway operation in the laboratory conditions. In: Manufacturing Technology. December 2013, Vol. 13, No. 4, Pp. 444-449. ISSN 1213-2489.

[6] HARUŠINEC, J., MAŇUROVÁ, M., SUCHÁNEK, A. (2016). Optimalization of a brake unit in terms of control range. In: Manufacturing Technology. August 2016, Vol. 16, No. 4, 2016. Pp. 917-923. ISSN 1213-2489.

[7] HARUŠINEC, J., SUCHÁNEK, A., GERLICI, J., LACK, T. (2012). Locomitive brake unit modification for laboratory experimental tests. In: Dynamics of rigid and deformable bodies 2012 (electronic scource): Proceedings of international scientific conference, Ústí nad Labem, Czech Republic, October 10-12, 2012, J. E. Purkyně University. CD-ROM, 9 pages. ISBN 978-80-7414-500-0.

[8] HAUSER, V., NOZHENKO, O. S., KRAVCHENKO, K. O., LOULOVÁ, M., GERLICI, J., LACK, T. (2016). Influance of axles steering and geometry of wheel profile on the vehicle behaviour in rail track curving (in Slovak). In: Dynamics of rigid and deformable bodies 2016 (electronic scource): Proceedings of international scientific conference, Ústí nad Labem, Czech Republic, October 5-7, 2016, J. E. Purkyně University. CD-ROM, 8 pages. ISBN 978-80-7561-016-4.

[9] LACK, T., GERLICI, J. (2016). Tangential stresses for non-elliptical contact patches computed by means of a modified FASTSIM method. In: Civil-Comp Proceedings [electronic scource]. - ISSN 1339-4509. - Iss. 1 (2016), online, [10] s. 
[10] LACK, T., GERLICI, J., MAŇUROVÁ, M. (2016). Freight car bogie properties analysis by means of simulation computations. In: Manufacturing Technology. August 2016, Vol. 16, No. 4, 2016. Pp. 667-672. ISSN 1213-2489.

[11] KLIMENDA, F., SOUKUP, J., ŽMINDÁK, M. (2016). Deformation of aluminium thin plate. In: Manufacturing Technology. February 2016, Vol. 16, No. 1, 2016. Pp. 124-129. ISSN 1213-2489.

[12] SVOBODA, M., SOUKUP, J. (2013). Verification of numeric solution by experiment for examination vertical oscillation of a mechanical system. In: Manufacturing Technology. December 2013, Vol. 13, No. 4, 2013. Pp. 559563. ISSN 1213-2489.

[13] SMETANKA, L., GERLICI, J., LACK, T., PELAGIĆ, Z. (2015). Homogenization of fibres reinforced composite materials for simulation analysis. In: Manufacturing Technology. November 2015, Vol. 15, No. 5, 2015. Pp. $914-$ 920. ISSN 1213-2489.

[14] SOUKUP, J., SKOČILAS, J., SKOČILASOVÁ, B. (2014). Vertical vibration of the vehicle model with higher degree of freedom. In: Modelling of Mechanical and Mechatronics Systems MMaMS 2014, In: Elsevier Ltd., Procedia Engineering 96 (2014) 435-443.

[15] ŠŤASTNIAK, P. (2015). Wagon chasis frame desing with adaptable loading platform. In: Manufacturing Technology. November 2015, Vol. 15, No. 5, 2015, Pp. 935-940. ISSN 1213-2489.

Copyright (C) 2017. Published by Manufacturing Technology. All rights reserved. 